\title{
Phenylalanine and tyrosine levels in newborn screening blood samples
}

\author{
A F MORRIS, J B HOLTON, D BURMAN, AND J R T COLLEY
}

Department of Community Health, University of Bristol, Department of Clinical Chemistry, Southmead Hospital, and Bristol Royal Hospital for Sick Children, Bristol

SUMMARY A previously described difference in newborn blood phenylalanine concentrations between those living in urban and non-urban areas in the south west of England has been confirmed and shown to be independent of the type of feed. Several factors including the place of abode, type of feed, birthweight, and the accuracy of the test have been found to affect the measured, phenylalanine concentration in the newborn screening blood spot, and the importance of these results to screening practice is considered. Blood tyrosine also varied with the above factors, but severe, neonatal tyrosinaemia was shown to be a rare problem.

In 1970 data from phenylketonuria screening blood samples of infants within the area of the South Western Regional Health Authority (comprising the counties of Avon, Cornwall, Devon, Gloucester, and Somerset) were analysed to determine factors influencing blood phenylalanine in the newborn period. ${ }^{1}$ Predictable effects of birthweight and age were found, but rather unexpectedly, babies living in urban areas had a significantly higher blood phenylalanine concentration than those in rural areas. Infant feeding varies throughout the region and we postulated that the consequent variation in protein intake might explain geographical differences in blood phenylalanine concentrations.

For a period of one year from February 1979, a second survey was undertaken to examine the influence on newborn blood phenylalanine, of feeding different types of milk and whether the apparent effect of the place of abode could be due to differences in feeding practice. Blood tyrosine was also estimated in order to study the prevalence of tyrosinaemia and the relation of this to the type of feed. Transient neonatal tyrosinaemia has been described as the most common amino acid disorder in man and the adverse effect of this on the subsequent intellectual development of the infant has been suggested. ${ }^{2}$

\section{Patients and methods}

The babies in this study comprised all those born between 1 February 1979 and 31 January 1980, whose home address was within the South Western
Health Region. Heelprick blood samples were taken on the seventh day of life and collected onto absorbent filter paper (Whatman no 160). The filter paper was attached to a request form on which was recorded information about the infant and details of the baby's feeds during the 48 hours before the test, including the brand of milk given to bottle fed babies.

The basic information on each infant was coded onto the back copy of the request form for statistical analysis. The home address was coded in two ways and this requires further explanation. The first was by its location in one of the five counties of the South Western Health Region. The second was by population size using figures from the 1971 census. County boroughs and districts, and municipal and urban districts were divided into three types of communities: 'large urban complex', with a population of 50000 or more'; 'medium urban' of 15000 to 49 999; and 'small urban' of less than 15000 . A fourth category comprised any rural district.

Phenylalanine and tyrosine were estimated simultaneously on $0.6 \mathrm{~cm}$ diameter discs, punched from the filter paper blood spots, using an automated fluorimetric method. ${ }^{3}$ Mean levels of phenylalanine and tyrosine were compared using one and two way analysis of variance tests and $\chi^{2}$ tests were used to analyse contingency tables.

\section{Results}

In total 37545 patients were screened between 
1 February 1979 and 31 January 1980 . The total live births, less the first week deaths for 1979, was 37 514. These figures are so similar it seems unlikely that many infants were missed. The recording of data was exceptionally good: the most frequent items omitted were the type of milk used in artificial feeding $(1.5 \%)$, and birthweight $(1.1 \%)$.

In the present study, $89 \%$ of all babies were tested at age six to eight days, and only $4 \%$ before the sixth day. There was a slight fall in phenylalanine and tyrosine levels after the eighth day, but no statistically significant differences between days six to eight. There was no statistically significant difference in mean values of phenylalanine or tyrosine between boys and girls, but as there was evidence of high levels of phenylalanine in low birthweight babies, we have confined our major analysis to the 31563 babies tested in days six to eight, of birthweight $2.5 \mathrm{~kg}$ or more (Figure).

Effect of county and district. To eliminate the possible effect on phenylalanine and tyrosine values of any local variation of feeding practice, we first

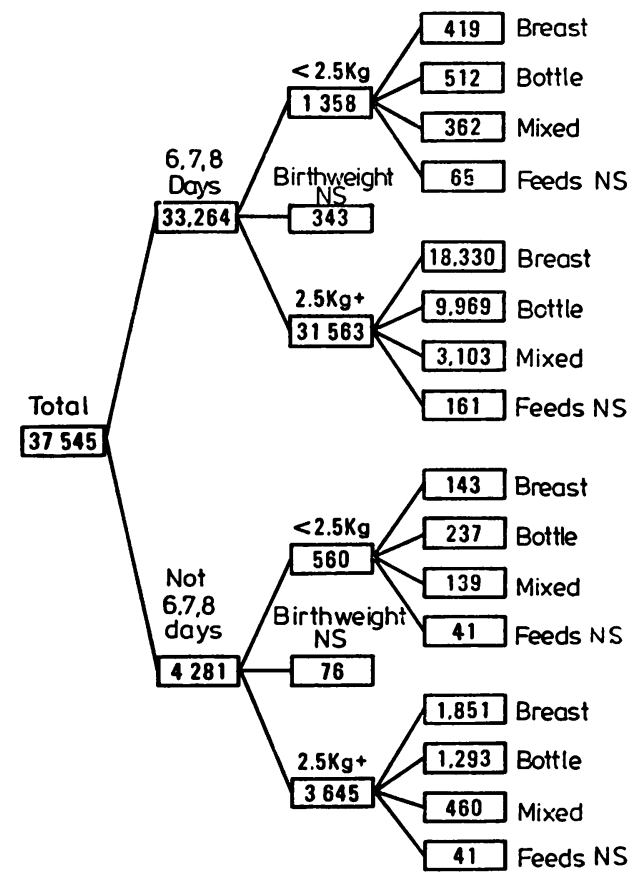

NS $=$ not stated

Figure Distribution of numbers of babies screened according to age at time of screening, birthweight, and type of feed. considered the 18330 infants who had been fully breast fed for the 48 hours before sampling (Figure). Because of the known association between blood levels of phenylalanine and tyrosine and birthweight, the distribution of birthweight by area and community was compared in both boys and girls, but no differences were found.

There are no large urban communities in Somerset or Cornwall. Considering medium and small urban, and rural communities only, in each of the five counties, an analysis of variance showed no statistically significant difference in mean phenylalanine between the three types of community in Somerset, Devon, and Cornwall. There were minor differences $(P<0.05)$ in the three types of community in Avon and Gloucestershire but no consistent pattern emerged. For further analysis, the figures for these three types of community have been combined, and will henceforward be referred to as 'non-urban communities'. There is a difference $(P<0.001)$ in the mean levels of phenylalanine in non-urban communities of the five counties, with higher levels in Somerset and Avon, and the lowest in Cornwall (Table 1). There is no statistically significant difference between the mean levels in large urban communities in the three relevant counties. There is, however, a statistically significant difference between large urban and non-urban districts in each of these counties $(P<0 \cdot 01)$, which is highly significant when the results are combined $(\mathrm{P}<0 \cdot 001)$.

Mean tyrosine values in breast fed babies were also

Table 1 Mean blood phenylalanine and tyrosine by county and community in breast fed infants with birthweight $2 \cdot 5 \mathrm{~kg}$ or more, tested on days 6,7 , or 8

\begin{tabular}{|c|c|c|c|c|c|}
\hline \multirow[t]{3}{*}{ County } & & \multicolumn{4}{|c|}{ Community } \\
\hline & & \multicolumn{2}{|c|}{ Large urban } & \multicolumn{2}{|c|}{ Non urban } \\
\hline & & Mean & $S D$ & Mean & $S D$ \\
\hline Avon & $\begin{array}{l}\text { Phenylalanine }(\mu \mathrm{mol} / 1) \\
\text { Tyrosine }(\mu \mathrm{mol} / 1) \\
\text { No of babies }\end{array}$ & $\begin{array}{l}119 \cdot 5 \\
150 \cdot 8\end{array}$ & $\begin{array}{l}36 \cdot 2 \\
51 \cdot 5 \\
53\end{array}$ & $\begin{array}{r}117 \cdot 0 \\
145 \cdot 3 \\
2\end{array}$ & $\begin{array}{l}32 \cdot 1 \\
46 \cdot 8 \\
60\end{array}$ \\
\hline Cornwall & $\begin{array}{l}\text { Phenylalanine }(\mu \mathrm{mol} / 1) \\
\text { Tyrosine }(\mu \mathrm{mol} / 1) \\
\text { No of babies }\end{array}$ & & & $\begin{array}{r}111 \cdot 1 \\
137 \cdot 8\end{array}$ & $\begin{array}{l}30 \cdot 6 \\
45 \cdot 3 \\
45\end{array}$ \\
\hline Devon & $\begin{array}{l}\text { Phenylalanine }(\mu \mathrm{mol} / \mathrm{l}) \\
\text { Tyrosine }(\mu \mathrm{mol} / \mathrm{l}) \\
\text { No of babies }\end{array}$ & $\begin{array}{r}118 \cdot 0 \\
143 \cdot 5 \\
2\end{array}$ & $\begin{array}{r}31 \cdot 1 \\
44 \cdot 0 \\
41\end{array}$ & $\begin{array}{r}113 \cdot 5 \\
141 \cdot 5 \\
2\end{array}$ & $\begin{array}{l}32 \cdot 2 \\
47 \cdot 9 \\
08\end{array}$ \\
\hline Glo'shire & $\begin{array}{l}\text { Phenylalanine }(\mu \mathrm{mol} / \mathrm{l}) \\
\text { Tyrosine }(\mu \mathrm{mol} / \mathrm{l}) \\
\text { No of babies }\end{array}$ & \multicolumn{2}{|c|}{$\begin{array}{c}14 / \cdot 73 \cdot 0 \\
1038\end{array}$} & $\begin{array}{r}115 \cdot 1 \\
141 \cdot 5 \\
1\end{array}$ & $\begin{array}{r}30 \cdot 1 \\
47 \cdot 3 \\
17\end{array}$ \\
\hline Somerset & $\begin{array}{l}\text { Phenylalanine }(\mu \mathrm{mol} / \mathrm{l}) \\
\text { Tyrosine }(\mu \mathrm{mol} / 1) \\
\text { No of babies }\end{array}$ & & & $\begin{array}{r}118 \cdot 1 \\
141 \cdot 8\end{array}$ & $\begin{array}{l}30 \cdot 7 \\
45 \cdot 8 \\
40\end{array}$ \\
\hline Total & $\begin{array}{l}\text { Phenylalanine }(\mu \mathrm{mol} / 1) \\
\text { Tyrosine }(\mu \mathrm{mol} / 1) \\
\text { No of babies }\end{array}$ & $\begin{array}{r}119 \cdot 0 \\
147 \cdot 6 \\
6\end{array}$ & $\begin{array}{r}33 \cdot 8 \\
48 \cdot 0 \\
32\end{array}$ & $\begin{array}{r}115 \cdot 3 \\
141 \cdot 8 \\
11\end{array}$ & $\begin{array}{l}31 \cdot 3 \\
46 \cdot 8 \\
70\end{array}$ \\
\hline
\end{tabular}

Conversion SI to traditional units-phenylalanine: $1 \mu \mathrm{mol} / 1 \approx 16.52$ $\mathrm{mg} / 100 \mathrm{ml}$; tyrosine : $1 \mu \mathrm{mol} / \mathrm{l} \approx 11 \cdot 11 \mathrm{mg} / 100 \mathrm{ml}$. 
higher $(P<0 \cdot 001)$ in large urban communities than in non-urban, Avon having the highest urban, and Cornwall the lowest non-urban levels (Table 1).

Babies fed each brand of artificial milk, except Baby Milk + , showed essentially the same difference in mean phenylalanine and mean tyrosine concentrations between large urban and non-urban communities as the breast fed infants. SMA Gold Cap was the most widely used formula feed, given to $57 \%$ of the wholly bottle fed babies; in these babies there were significant differences in mean phenylalanine and mean tyrosine between communities $(P<0 \cdot 01)$ but not between counties (Table 2$)$.

Infant feeds. In the sample of infants of birthweight $2.5 \mathrm{~kg}$ or more, tested on days six to eight, there was a highly significant $(P<0.001)$ overall difference between the mean phenylalanine (but not the mean tyrosine) value of breast fed babies and those wholly bottle fed for 48 hours before testing (Table 3 ). The phenylalanine results did not appear to reflect the protein content of the different types of artificial milk used in the region, Baby Milk + giving the only outstandingly high mean value. There was a wide variation in the mean tyrosine concentration by

Table 2 Mean blood phenylalanine and tyrosine by county and community in infants with birthweight $2.5 \mathrm{~kg}$ or more, tested on days 6,7 , or 8 and fed on SMA Gold Cap

\begin{tabular}{|c|c|c|c|c|}
\hline \multirow[t]{2}{*}{ Count, } & \multicolumn{2}{|l|}{ Large urban } & \multicolumn{2}{|c|}{ Small urban and rural } \\
\hline & $\begin{array}{l}\text { Phenylalanine } \\
\text { ( } \mu \mathrm{mol} / \mathrm{l})\end{array}$ & $\begin{array}{l}\text { Tyrosine } \\
\text { ( } \mu \mathrm{mol} / \mathrm{l})\end{array}$ & $\begin{array}{l}\text { Phenylalanine } \\
\text { ( } \mu \mathrm{mol} / \mathrm{l})\end{array}$ & $\begin{array}{l}\text { Tyrosine } \\
(\mu \mathrm{mol} / \mathrm{l})\end{array}$ \\
\hline $\begin{array}{l}\text { Avon } \\
\text { Cornwall } \\
\text { Devon } \\
\text { Glo'shire } \\
\text { Somerset }\end{array}$ & $\begin{array}{l}126 \cdot 7 \\
125 \cdot 2 \\
126 \cdot 3 \\
-\end{array}$ & $\begin{array}{l}137 \cdot 0 \\
\overline{137} \cdot 8 \\
137 \cdot 3 \\
-\end{array}$ & $\begin{array}{l}122 \cdot 1 \\
119 \cdot 4 \\
118 \cdot 4 \\
119 \cdot 7 \\
120 \cdot 6\end{array}$ & $\begin{array}{l}134 \cdot 2 \\
128 \cdot 4 \\
135 \cdot 5 \\
130 \cdot 4 \\
133 \cdot 3\end{array}$ \\
\hline Total & $126 \cdot 3$ & $137 \cdot 2$ & $120 \cdot 3$ & $132 \cdot 0$ \\
\hline
\end{tabular}

Table 3 Mean blood phenylalanine and tyrosine by type of milk in infants with birthweight $2.5 \mathrm{~kg}$ or more and tested on days 6,7 , or 8

\begin{tabular}{|c|c|c|c|c|c|}
\hline Type of milk & Protein & kcal & $\begin{array}{l}\text { No of } \\
\text { babies }\end{array}$ & $\begin{array}{l}\text { Phenylalanine } \\
(\mu \mathrm{mol} / \mathrm{l})\end{array}$ & $\begin{array}{l}\text { Tyrosine } \\
\text { ( } \mu \mathrm{mol} / \mathrm{l})\end{array}$ \\
\hline $\begin{array}{l}\text { Breast milk } \\
\text { Mixed breast }\end{array}$ & - & 一 & 18321 & $116 \cdot 4$ & $143 \cdot 8$ \\
\hline and bottle & 一 & 一 & 3100 & $117 \cdot 7$ & $138 \cdot 7$ \\
\hline All bottle & 一 & 一 & 9965 & $124 \cdot 2$ & $143 \cdot 4$ \\
\hline Baby Milk + & $1 \cdot 85$ & 65 & 1962 & $127 \cdot 2$ & 164.9 \\
\hline Premium & $1 \cdot 8$ & 65 & 650 & $123 \cdot 5$ & $131 \cdot 3$ \\
\hline Ostermilk & $1 \cdot 7$ & 65 & 844 & $124 \cdot 7$ & $164 \cdot 3$ \\
\hline SMA Gold Cap & $1 \cdot 6$ & 66 & 5635 & $123 \cdot 0$ & $134 \cdot 3$ \\
\hline Osterfeed & 1.45 & 68 & 321 & $124 \cdot 1$ & $133 \cdot 1$ \\
\hline
\end{tabular}

Table 4 Variation of mean blood phenylalanine and tyrosine with birthweight in breast fed infants tested on days 6,7 , or 8

\begin{tabular}{|c|c|c|c|c|c|}
\hline \multirow[t]{2}{*}{ Birthweight } & \multirow[t]{2}{*}{$\begin{array}{l}\text { No of } \\
\text { babies }\end{array}$} & \multicolumn{2}{|c|}{$\begin{array}{l}\text { Phenylalanine } \\
\text { ( } \mu \mathrm{mol} / \mathrm{l})\end{array}$} & \multicolumn{2}{|c|}{$\begin{array}{l}\text { Tyrosine } \\
(\mu \mathrm{mol} / \mathrm{l})\end{array}$} \\
\hline & & Mean & $S D$ & Mean & $S D$ \\
\hline $\begin{array}{r}<2.0 \mathrm{~kg} \\
2.0 \mathrm{~kg} \\
2.5 \mathrm{~kg} \\
3.0 \mathrm{~kg} \\
3.5 \mathrm{~kg} \\
>4.0 \mathrm{~kg}\end{array}$ & $\begin{array}{r}45 \\
374 \\
2663 \\
7666 \\
6063 \\
1929\end{array}$ & $\begin{array}{l}132 \cdot 8 \\
121 \cdot 2 \\
117 \cdot 5 \\
116 \cdot 0 \\
115 \cdot 8 \\
118 \cdot 3\end{array}$ & $\begin{array}{l}32 \cdot 3 \\
33 \cdot 9 \\
32 \cdot 3 \\
31 \cdot 8 \\
32 \cdot 8 \\
32 \cdot 5\end{array}$ & $\begin{array}{l}210 \cdot 6 \\
159.4 \\
147 \cdot 0 \\
143 \cdot 4 \\
143 \cdot 6 \\
141 \cdot 7\end{array}$ & $\begin{array}{r}155 \cdot 9 \\
60 \cdot 4 \\
49 \cdot 7 \\
46 \cdot 9 \\
47 \cdot 5 \\
44 \cdot 3\end{array}$ \\
\hline
\end{tabular}

different milks, and Baby Milk + and Ostermilk were associated with exceptionally high mean values (Table 3).

Birthweight. Table 4 shows that in breast fed infants phenylalanine and tyrosine are highest in those of low birthweight. Tyrosine levels greater than $450 \mu \mathrm{mol} / 1$ were found in 56 infants, 17 of whom weighed less than $2 \mathrm{~kg}$ at birth. There were 6 cases only with tyrosine levels of $1000 \mu \mathrm{mol} / 1$ or more and three of these weighed less than $2 \mathrm{~kg}$ at birth. The highest level recorded was $1700 \mu \mathrm{mol} / 1$.

\section{Discussion}

Four reasons for the regional variations in blood spot phenylalanine can be postulated: different feeding practices; artefacts introduced by screening practices which affect the measured blood phenylalanine level; genetic variation in phenylalanine metabolism between communities; and differing environmental factors affecting phenylalanine metabolism. We have obtained some evidence on the first two of these possibilities.

The contribution made by the type of feed to regional variations in phenylalanine values has been examined by considering homogeneous feeding groups. The largest of these is the breast feeding group; and in this group regional variations in phenylalanine concentrations persisted. It may be that differences in the quality of breast milk produce these variations. For example, mature breast milk of Bristol mothers was shown to contain more protein than that of mothers from other cities in Great Britain. ${ }^{4}$ This seems an unlikely explanation, however, because the largest formula milk feeding group (SMA Gold Cap) showed essentially the same differences between large urban and non-urban communities as the breast fed group.

In general the geographical pattern of blood tyrosine concentrations was similar to that found for blood phenylalanine. As both these estimations were obtained from the same blood sample, 
differences could arise through some artefact, such as variations in method of blood collection, time of collection in relation to feeds, assay technique, or the age of the blood spot. It seems unlikely that geographical differences could arise from the first three of these factors, since their effects would be randomly distributed. When blood spots are kept in the laboratory, however, a reduction in the phenylalanine concentration has been observed over a period of several weeks. Because of this, a small study was undertaken to see whether there was any evidence of undue delay in the processing of blood spots from any particular area or community, which could have a systematic effect on the results. The findings showed no difference in either the distribution or median value of the time lag in processing blood spots between samples from large urban communities and those from all other communities. Taking each community separately, there was no suggestion of a correlation between median time lag and previously observed mean phenylalanine levels.

When the contribution of the type of feed to the phenylalanine and tyrosine concentrations was considered, it was found that bottle fed babies had a higher mean blood phenylalanine value than breast fed babies. The mean value associated with each brand of milk used was higher than that for any group of breast fed infants. There was no difference in the mean blood tyrosine of the two broad categories, (breast fed and bottle fed), but when individual brands of milk were considered, big differences appeared. Baby Milk + and Ostermilk were associated with very high concentrations of blood tyrosine, while the mean for each of the other three brands was lower than that for any geographical group of breast fed babies. Many of the differences in mean phenylalanine, and particularly mean tyrosine values, with type of feed were large in relation to those described for other geographical areas. Thus, although the use of various brands of milk tended to be zoned geographically, this alone could not account for their contribution to the phenylalanine and tyrosine values.

The 1970 screening survey ${ }^{1}$ and the survey reported in this paper indicate that infant blood phenylalanine is influenced by geographical location, type of feed, and birthweight. The effect of each factor is small, but each may be of practical importance in the operation of a screening programme; firstly, in defining a 'cut off' level above which a repeat blood sample should be taken and, secondly, in considering if it is feasible to detect degrees of mild phenylalaninaemia which may require long term paediatric follow up.

The 'cut off' level widely employed since phenylketonuria screening was introduced is $240 \mu \mathrm{mol} / 1$ and a recent survey from the largest screening centre in England has concluded that this point is still appropriate..$^{5}$ Our data show that a phenylalanine level of $240 \mu \mathrm{mol} / 1$ corresponds approximately to the 99.75th centile, overall. By applying this 'cut off' point universally, however, the recall rate will vary significantly between counties, and also with the type of feed. For example, bottle fed babies in Avon would have a recall rate of $0.5 \%$, whereas for breast fed babies in Somerset or Cornwall it would be closer to $0 \cdot 15 \%$. The actual overall repeat rate on the sample of infants described in this paper was $3.3 \%$, because a lower 'cut off' value was used, but variations around this mean are consistent with the predicted variations in different groups of infants. For example, $4.0 \%$ of infants from large urban communities were recalled, but only $3.0 \%$ from the remainder $; .4 \%$ of bottle fed infants were recalled, but only $2.7 \%$ breast fed infants. The effect of birthweight was also marked: $9.1 \%$ of infants less than $2 \mathrm{~kg}$ were recalled.

During statistical analysis it became apparent that the accuracy of the phenylalanine method was another major determinant of the recall rate. The monthly mean for blood phenylalanine (each based on from two to three thousand tests) varied from 100 to $139 \mu \mathrm{mol} / \mathrm{l}$. The monthly recall rate varied six fold, being inversely related to the prevailing mean phenylalanine value. A similar phenomenon was found by Walker et al.,5 their annual recall rate fluctuating by a factor of 10 . These variations in analytical accuracy will be most important when considering the significance of small increases in blood phenylalanine.

The Medical Research Council Working Party on phenylketonuria has recently recommended that babies with blood phenylalanine of more than $240 \mu \mathrm{mol} / 1$ should be kept under long term surveillance. $^{6}$ It is presumed that the object is to distinguish those babies with an inherent tendency to mild hyperphenylalanineamia which may be of clinical significance. This survey indicates that screening blood phenylalanine levels of about 240 $\mu \mathrm{mol} / \mathrm{l}$ are affected by laboratory accuracy and other complex factors. The mass screening procedures in present use effectively identify babies with very high blood phenylalanine, who are possibly suffering from phenylketonuria, but they are unlikely to make the diagnosis of permanent mild hyperphenylalaninaemia with any certainty.

Transient neonatal tyrosinaemia was originally found to be a common occurrence. ${ }^{7}$ Mild tyrosinaemia was detected in $10 \%$ of term infants. The severe form appeared to be a problem in preterm infants predominantly, with a maximum blood tyrosine level at six to eight days of age. ${ }^{8}$ Over $25 \%$ 
of preterm infants on a moderately high, protein feeding regimen, had a blood tyrosine concentration of over $1 \mathrm{mmol} / 1$, and over half of these had values greater than $450 \mu \mathrm{mol} / 1$. This survey shows a changed situation. Only $3.3 \%$ of babies less than $2 \mathrm{~kg}$ birthweight had a blood tyrosine value of over $450 \mu \mathrm{mol} / 1$, while only six babies (three of low and three of normal birthweight) had tyrosinaemia greater than $1 \mathrm{mmol} / \mathrm{l}$. This supports the recent conclusions of Walker et al. ${ }^{5}$ that with the introduction of low protein milk formulae transient tyrosinaemia became rare. Tyrosinaemia may still, however, be a complication in very low birthweight babies fed special, high protein milks.

We thank Mr M G Gillett for skilled supervision of the laboratory work and Mrs Mary Probert for her part in processing the data.

\section{References}

1 Burman D, Holton J B, Morris A F. Factors determining blood phenylalanine in the neonatal period. Clin Chim Acta 1975; 62: 325-31.

2 Scriver C R, Rosenberg L E. Amino acid metabolism and its disorders. Philadelphia: Saunders, 1973: 345-8.
3 Blau K, Summer G K, Edwards D J. Automated simultaneous determinations of phenylalanine and tyrosine by a combined fluorimetric procedure. Adv Automated Analysis 1972; 1: 21-4.

4 Working Party of the Committee on Medical Aspects of Food Policy. The composition of mature human milk. London: HMSO, 1977: 16.

5 Walker V, Clayton B E, Ersser R S, et al. Hyperphenylalaninaemia of various types among three-quarters of a million neonates in a screening programme. Arch Dis Child 1981; 56: 759-64.

- Medical Research Council Steering Committee for the MRC/DHSS Phenylketonuria Register. Routine neonatal screening for phenylketonuria in the United Kingdom 1964-78. Br Med J 1981;282: 1680-4.

7 Marples E, Gordon H H. A defect in the metabolism of tyrosine and phenylalanine in premature infants. I. Identification and assay of intermediary products. J Clin Invest 1941; 20: 199-203.

8 Avery M E, Clow C L, Menkes J H, et al. Transient tyrosinaemia of the newborn: dietary and clinical aspects. Pediatrics $1967 ; 39$ : 378-84.

Correspondence to Dr J B Holton, Department of Clinical Chemistry, Southmead Hospital, Westburyon-Trym, Bristol BS10 5NB.

Received 31 December 1982 